\title{
Paleopathologic Diagnosis Based on Experimental Mummification
}

\author{
MICHAEL R. ZIMMERMAN \\ Departments of Pathology and Anthropology, The University of Michigan, \\ Ann Arbor, Michigan 48109
}

\begin{abstract}
KEY WORDS Paleopathology - Experimental mummification . Diagnosis
\end{abstract}

\begin{abstract}
The difficulties of diagnosis of pathologic conditions are immensely magnified when the subject of a postmortem examination has been postmortem for several hundreds to thousands of years. Artefacts of decomposition and bacterial and fungal invasion are compounded upon those of rehydration when mummified tissue is examined. As an approach to these problems, a study of the changes seen in experimentally mummified and rehydrated tissues was undertaken. Normal and pathologic tissues were studied in comparison to sections prepared from the fresh tissue.

The experimentally mummified tissues were generally similar to, but somewhat better preserved than, actual human mummies. There was organ and tissue specific variability in preservation, and different classes of pathology likewise showed differential preservation. Inflammatory reactions were not very well-preserved although infecting microorganisms were easily identified. Degenerative processes such as atherosclerosis and others characterized by the accumulation of abnormal products, were well preserved, while necrosis, as in acute myocardial infarction, was not. Malignancies were particularly well preserved. The implications of these findings for previous and future mummy studies is discussed in terms of our understanding of the evolution of disease processes.
\end{abstract}

Disease and death are integral parts of the history not only of inidividuals but of whole populations as well. Paleopathology aims at improving our understanding of the evolution of diseases and their role in human biologic and social history.

There has been much speculation on the role of disease in human evolution (Cockburn, '71, '67) and microevolution (St. Hoyme, '69; Brothwell and Sandison, '67; Angel, '66). Pathogenic organisms and the patterns of disease they cause evolve just as do larger organisms, including the hosts and vectors of disease. The clearest example of the evolution of a disease is the relatively recent development in Africa of falciparum malaria. The clearing of land for agricultural use produced an environment favorable to a species of mos. quito which happened to be a more efficient vector for Plasmodium falciparum. The result was an increase in this type of malaria and a decrease in the other forms of the disease (Wiesenfeld, '67). The increase in falciparum malaria resulted in a selective pressure for the protective sickle cell mutation (Livingstone, '69), a disease evolving in response to another disease.

On the other hand, there is evidence for considerable stability in some other host-parasite relationships. Similar parasitic infections have been found in Egyptian mummies and in modern Egyptians (Reyman et al., '77; Cockburn et al., '75). There is also a significant degree of similarity or actual identity of a number of human and nonhuman primate infections despite millions of years of divergent evolution of the respective genera (Coatney et al., '71; Cockburn, '71).

Evaluation of diseases over time requires information on ancient disease patterns, 
which can be obtained from several sources. Our present concept of diseases in past populations is based primarily on historic records such as the Egyptian medical papyri (Dawson, '67; Breasted, '34) and studies of the role of epidemic diseases in the decimation of the indigenous populations after European colonization of the New World (Cook, '73; Stearn and Allen, '45; Carter, '31) and Polynesia (Wright-St Clair, '74). Accounts of the great plagues of medieval Europe (Sloan, '74; Reisman, '35) and epidemics in the more recent past (Katz, '74; Bloch, '73a,b; Lipson, '72; Zinsser, '63) are also useful.

Works of art are another source which often give information on disease. These include such diverse media as paintings (Flanagan, '73; Janssens, '70), pottery effigies (von Hagen, '64), figurines and religious statuary (Stevenson, '75; Goldman, '74; Hart, '70), and figures and faces on coins (Beatty, '74; Hart, '73).

Examination of skeletal material (Goldstein, '70; Brothwell, '68; Brothwell and Sandison, '67) and mummies (Zimmerman, '73a; Sandison, '70) yields the most reliable paleopathologic information. As most diseases leave little or no direct mark on the skeleton, mummies, defined as bodies preserved either naturally or artifically, hold a much greater potential for paleopathologic examination. Postmortem examinations can be performed on mummies, and the diagnosis of many conditions can be made with relative confidence and accuracy.

On the other hand, the microscopic diagnosis of pathologic conditions in modern surgical and autopsy specimens often presents considerable difficulties to even the most experienced pathologist. These problems are immensely magnified when the subject of a postmortem examination has been postmortem for several hundreds to thousands of years. Some degree of autolysis is inevitable before the proteolytic enzymes of the tissues and invading bacteria and fungi are inactivated by the mummification process. In fresh tissue, bacteria and fungi can be recognized as postmortem invaders by the absence of an inflammatory reaction, but it can be very difficult to recognize such a reaction in mummified tissues. Even the underlying structure of the tissue may be difficult to recognize, depending on the adequacy of mummification.

Rehydration of desiccated tissue is based on the use of a solution of water, alcohol and sodium carbonate developed by Ruffer ('21). While the rehydrated tissue is processed in the same fashion as fresh tissues, the artefacts of rehydration are compounded upon those of decomposition and desiccation.

As an approach to these problems, I undertook a study of the changes seen in experimentally mummified and rehydrated tissues, both normal (Zimmerman, '72) and with known pathologic conditions. Tissues were taken from human cadavers, oven dried, rehydrated and examined microscopically in an effort to delineate the various changes in appearance produced by these processes.

\section{MATERIALS AND METHODS}

The tissues studied were obtained from adult human cadavers undergoing postmortem examination, all within 24 hours after death. Specimens measuring approximately one cubic centimeter were taken from areas appearing grossly abnormal at postmortem examination. The various lesions were selected as being representative of several broad classes of disease: inflammatory and degenerative disorders, disturbances of circulation, and neoplasms. Most of the common disorders of the major organs were included.

Each specimen was bisected. One-half was placed immediately in $10 \%$ formalin, and, after a 24-hour period of fixation, was embedded in paraffin for sectioning. The other half was placed in an Elconap oven at $40^{\circ} \mathrm{C}\left(104^{\circ} \mathrm{F}\right)$ for 7 to 14 days. After this period the specimens were dry, dark brown and reduced to approximately $10 \%$ of their original weight. The specimens were rehydrated with a solution of 50 parts water, 30 parts absolute alcohol, and 20 parts of a $5 \%$ sodium carbonate solution. It was found that rehydration for one or two days was adequate (Allison, personal communication). The specimens were then fixed in absolute alcohol for one to three days and embedded in paraffin. The paraffin blocks were sectioned on a Spencer Rotary Microtome. The sections were stained according to the techniques given in the Armed Forces Institute of Pathology Manual of Histologic Methods (Luna, '68). All sections were stained with the standard Hematoxylin and Eosin (H\&E) which stains nuclei blue and cytoplasm pink. A number of special stains were also used: Masson Trichrome (nuclei black, muscle bright red, cytoplasm red and collagen blue), Verhoeff Elastic (elastin black), AldehydeFuchsin (elastin purple), Alizarin-Red (calci- 
TABLE 1

\begin{tabular}{|c|c|c|c|}
\hline \multirow{2}{*}{ Diseases } & \multicolumn{3}{|c|}{ Characteristics } \\
\hline & Present & Absent & Equivocal \\
\hline \multicolumn{4}{|l|}{ Inflammatory lesions } \\
\hline Acute & $\mathrm{X}$ & & \\
\hline Chronic & & & $\mathrm{X}$ \\
\hline Granulomatous & $\mathrm{X}$ & & \\
\hline Osteomyelitis & & $\mathrm{X}$ & \\
\hline \multicolumn{4}{|l|}{ Degenerative processes } \\
\hline Dissecting aneurysm & $\mathrm{x}$ & & \\
\hline Atelectasis & & $\mathrm{x}$ & \\
\hline Fatty change of liver & $\mathrm{x}$ & & \\
\hline Cirrhosis & $\mathrm{X}$ & & \\
\hline Fibrosis & $\mathrm{X}$ & & \\
\hline Paget's disease of bone & $\mathrm{X}$ & & \\
\hline \multicolumn{4}{|l|}{ Disturbances of circulation } \\
\hline Thrombosis & & & $\mathrm{x}$ \\
\hline Acute myocardial infarction & & $\mathrm{X}$ & \\
\hline Healed myocardial infarction & $\mathrm{X}$ & & \\
\hline Chronic passive congestion & $\mathrm{X}$ & & \\
\hline Embolization & $\mathrm{x}$ & & \\
\hline Hemorrhage & & $\mathrm{x}$ & \\
\hline \multicolumn{4}{|l|}{ Neoplasms } \\
\hline Carcinoma of lung & $\mathrm{X}$ & & \\
\hline Carcinoma of breast & $\mathrm{X}$ & & \\
\hline Carcinoma of colon & & $\mathrm{X}$ & \\
\hline Carcinoma of prostate & $\mathbf{x}$ & & \\
\hline Leukemia & $\mathrm{X}$ & & \\
\hline Metastatic carcinoma & $\mathrm{X}$ & & \\
\hline
\end{tabular}

um red), Kinyoun's Acid-Fast (AFB, tubercle bacilli red), Brown-Brenn Gram stain (for bacteria), Fontana (argentaffin granules black), Giemsa (for hematopoietic and blood cells), Gomori Iron stain (iron blue), Grocott (fungi and vegetable matter black), Mallory Phosphotungstic Acid Hematoxylin (PTAH, for fibrin, red cells, and muscle striations), Methyl Green Pyronin (MGP, plasma cell cytoplasm red), Muci-carmine (mucin red), $\mathrm{Pe}$ riodic Acid Shiff (PAS, fungi, parasites, vegetable matter purple), and Reticulin (reticulin fibers black). Certain lesions were also examined with polarized light.

The slides were numerically coded and examined as relative unknowns several weeks or months after their preparation. The slides of the mummified tissue were examined first and then compared to the fresh tissue control slides.

\section{RESULTS}

The results of the study are summarized in table 1.

\section{Inflammatory lesions}

Inflammatory cells were generally not as well preserved by mummification as the causative organisms in cases of infection. The growth of bacteria and particularly fungi (fig. 1) was found to be arrested by desiccation, even in areas of destruction of the surrounding tissue by the infectious process. Chronic inflammation showed some variability in preservation, the granulomas of sarcoidosis (pathologically similar to tuberculosis) remaining recognizable, while an example of chronic osteomyelitis was indistinguishable from carcinoma metastatic to bone.

\section{Degenerative processes}

Diagnosis of a mummified dissecting aneurysm of the aorta was greatly facilitated by the use of specific stains. An elastic tissue stain differentiatied between the dissecting blood clot and the highly elastic aortic wall and PTAH stained the fibrin and erythrocytes of the clot a deep blue in contrast to the red of the media.

Mummification preserved well fatty change of the liver, an effect of exogenous toxins (most commonly ethyl alcohol). Continued exposure to such toxins results in cirrhosis, a fibrotic disruption of the general architecture 
of the liver (fig. 2a), with particular disruption of the vital and delicate relationship between the biliary and circulatory systems of the liver. A mummified cirrhotic liver showed preservation of the characteristic division into pseudolobules by fibrous bands and of areas of bile duct reduplication (fig. 2b) .

The accumulation of anthracotic pigment in the lymphatics of the lung is a process seen in almost all humans due to exposure from smoke from various sources. The black pigment is still easily seen after mummification. In contrast, focal collapse of the lung, atelectasis (a condition associated with bed rest) was not diagnosable in the mummified tissue. The lung in this case presented a very uniform and unremarkable appearance.

Paget's disease of bone presents a very characteristic mosaic microscopic pattern. The mummified tissue showed the thickened bone spicules but the mosaic pattern, although still discernable, was not as evident as in the fresh tissue.

\section{Disturbances of circulation}

The deposition of fat and cholesterol in the walls of arteries in athero-sclerosis is well preserved by mummification. The characteristic cholesterol clefts and calcification were easily identified.

Such arteries, with their roughened walls and comprised lumina, are liable to occlusion by thrombosis. A mummified thrombosed coronary artery showed preservation of calcific atherosclerosis but the thrombus was reduced to eosinophilic material indistinguishable with $H \& E$ from a mummified blood clot. PTAH, which showed very well the exquisite fibrin meshwork of the thrombus in the control slide, stained the material in the lumen of the mummified vessel a diffuse blue. The red cells and fine detail of the fibrin were no longer seen but the meshlike pattern remained.

Such coronary thrombosis is associated with myocardial infarction ("heart attack"), death of large areas of the heart muscle. A classical acute myocardial infarct could not be diagnosed in the mummified material. The mummified necrotic muscle could not be distinguished from the adjacent autolyzed myocardium and only a suggestion of the acute inflammatory reaction remained. In contrast, the fibrosis of a healed infarct showed up very well, particularly with a trichrome stain. Lipofuscin, a degenerative pigment seen in the organs of the aged, was well preserved in both the healed infarct and the adjacent myocardium.

Chronic heart failure due to such fibrosis leads to chronic passive congestion and edema of various organs. The red cells break down, with accumulation of hemosiderin, an iron containing brown pigment, in the tissues. Hemosiderin was easily identified in chronically congested lung, liver, and spleen, particularly with the iron stain.

Blood vessels can also be occluded by emboli, represented in this study by bone marrow emboli to the lung, secondary to trauma at the time of death (fig. 3a). The characteristic admixture of hematopoietic cells and adipose tissue was clearly seen in small vessels in the lung after mummification (fig. $3 \mathrm{~b}$ ).

Disease of smaller vessels, such as renal arterior sclerosis (often associated clinically with hypertension), was not recognizable after mummification, even though the glomeruli remained fairly well preserved. Areas of hemorrhage were also poorly preserved.

\section{Neoplasms}

Both primary and secondary (metastatic) malignant tumors were included in this study. Two variants of carcinoma of the lung remained recognizable as masses replacing most of the lung. The malignant nature of the tumor cell nuclei was well preserved.

Breast cancer is characterized by infiltration of the breast by rows and sheets of malignant cells, occasionally forming a poorly differentiated glandular pattern (fig. 4a). The mummified tumor lost this glandular pattern but was still diagnosable as a malignancy consisting of infiltrating sheets of malignant cells (fig. $4 \mathrm{~b}$ ).

There was some variability in the preservation of other tumors. Bowel tumors were autolyzed and unrecognizable while cancer of the prostate and leukemic infiltrates could be recognized.

Metastatic tumors are of particular interest in that the microscopic pattern is on occasion sufficiently distinctive that the site of origin can be suggested with a good degree of confidence. For example, papillary carcinoma, which originates most commonly in the ovary or thyroid gland, tends to form whorled calcific structures called psammoma bodies. These structures are well preserved by mummification.

Adenocarcinomas (glandular cancers) gen- 
erally indicate an origin somewhere in the gastrointestinal tract or occasionally in the lung. Metastatic adenocarcinoma from the colon to the liver (fig. 5a), lung, and bone was examined. In each case, the mummified tissue showed preservation of the atypical glandular pattern and, particularly in the liver (fig. 5b) of the large, pleomorphic malignant nuclei. The tumors were also generally better preserved than the adjacent normal tissue.

Examination of less distinctive metastatic tumors produced expected results. The presence of tumor was apparent but the tissue of origin (in these cases breast and lung) could not be determined.

\section{DISCUSSION}

This experimental approach produces changes similar to those observed by the author and others in the tissues of actual human mummies. The actual mummies are not quite as well preserved, especially the nuclei of the cells. This is probably due to slower or more erratic desiccation and more severe bacterial and fungal contamination. The results of this experimental study do permit the making of a number of general and specific comments and some extrapolations to actual mummies.

A significant degree of variability was observed in the preservation of pathological lesions. While it was almost always possible to make the correct diagnosis, specific difficulties were noted with the different classes of disease.

Among the inflammatory conditions, it was noted that non-specific processes were disappointing in their degree of preservation, probably because of the minimal changes in these conditions. There is a definite problem in identifying the neutrophil, the cell of acute in. flammation. These cells are in essence containers of proteolytic enzymes and after death they lose their self-protective mechanisms and autolyze very quickly, assuming an irregular basophilic granular appearance, if they remain to be seen at all. Similar appearing intravascular structures have been interpreted as autolyzed neutrophils in mummies (Reyman et al., '77; Riddle et al., '75; Zimmerman, ' $73 \mathrm{~b}$ ), and the results of this study confirm these authors' impressions.

The cells of chronic inflammation, lymphocytes, plasma cells, and histiocytes, do not have quite the same self-destructive tendencies, and are thus better preserved. The first two appear as indistinguishable round cells. Larger histiocytes remain better preserved. A less equivocal diagnosis of chronic inflammation can be made on seeing these distinc tive cells.

Pulmonary inflammation was generally well preserved, as the aeration of the lung allows rapid desiccation, preventing the severe autolysis seen in the solid viscera. Specific stains for bacteria revealed marked postmortem multiplication. In contrast, fungi tended to remain much more localized after mummification. Thus, wide dissemination of fungi in the tissues of a mummy probably indi. cates postmortem contamination and inadequate mummification. An example is the widespread fungus seen in an Eskimo mummy in 1975 (Zimmerman and Smith, '75); the probability is that this frozen mummy had been thawed and refrozen at various intervals throughout its 1,600 year course.

Tubercle bacilli have been identified in ancient material (Zimmerman, '78; Allison et al., '73) and an attempt was not made to duplicate this finding experimentally, in consideration of the health hazard posed by drying tissue containing living tubercle bacilli. A case of sarcoidosis, which shows similar pathology, was examined, and the diagnosis easily made. Again, the experimental findings support previous interpretations.

The case of osteomyelitis examined proved to be a problem, in that it was indistinguishable from metastatic undifferentiated carcinoma. The diagnosis of osteomyelitis can be difficult in fresh tissue, and the carryover of this difficulty into the realm of mummified tissue must be accepted.

The degenerative processes were quite well preserved in the mummified tissue, often appearing little different from the fresh tissue. These conditions are generally characterized by the accumulation of various tissues and foreign materials which tend to be remarkably inert and persistent. Examples are fat, cholesterol, various pigments, and fibrous tissue. Again, relatively non-specific processes, such as mild pulmonary atelectasis, were found to be non-diagnostic after mummification.

A mummified fatty liver was found to be much better preserved than normal liver, and it may be that the fat acted as adipocere on the microscopic level in this case. Adipocere is a soap-like decomposition product of fat which has an antibacterial preservative effect on the 
tissue around it, at least at the gross level (Evans, '63; Mant, '57). Certainly the spread of the gas forming bacteria which usually destroy the structure of the liver was markedly inhibited in this case.

Tissues of mesenchymal origin, such as fibrous and elastic tissue, are well known to be better preserved in mummies than are epithelial tissues (Sandison, '70), although it is actually the intercellular collagen and elastin which persists, the cells themselves degenerating. Thus a cirrhotic liver remained diagnosable, as did fibrosis in the lung. A useful technical point was noted in the latter case. Pulmonary fibrosis is at the expense of elastic tissue. The usual stain for elastin, the Verhoeff, stains it black, producing some confusion with anthracotic pigment. The carbon of anthracotic pigment is totally inert, extraordinarily persistent, and ubiquitous, having been described in mummies from all areas of the world (Cockburn et al., '75; Zimmerman and Smith, '75; Zimmerman et al., '71; Brothwell et al., '69; Shaw, '38). Elastin is purple with the Aldehyde-fuchsin stain, avoiding this confusion.

Another persistent pigment was found to be lipofuscin, a degenerative brown pigment found in the heart and liver. This change is age associated and suggests atrophy of the organ involved. It has been reported in the liver of one mummy (Zimmerman and Smith, '75).

The ability to diagnose Paget's disease of bone is important. In modern populations nearly $60 \%$ of bone sarcomas arising in those over 40 years of age are associated with Paget's disease (Aegerter and Kirkpatrick, '75). This disease affects up to $30 \%$ of those over 40 (Lichtenstein, ' 70 ), and accounts for the second peak in incidence of osteosarcoma in the aged, the first peak being in the second and third decades of life. Osteosarcoma is exceedingly rare in ancient material, being limited to a few possible cases diagnosed in skeletal material (Miller, '29; Ruffer and Willmore, '14), and the finding of Paget's disease would indicate an individual at least more susceptible to this disease. Conversely, the great rarity of osteosarcoma in antiquity raises questions about its etiology, which is unknown but could be related to factors pres ent only in modern societies.

In contrast to the degenerative processes, conditions of disturbance of circulation were generally not as well preserved. Arterioscle- erosis of small vessels was not recognizable, but atherosclerosis of large vessels was well seen. Again, this is a process of deposition of inert materials, in this case fat, cholesterol, and calcium.

Blood clotting is a postmortem or extravascular phenomenon and differs both grossly and microscopically from antemortem thrombosis, which consists of red and white blood cells suspended in a meshwork of fibrin and platelets. In an example of coronary thrombosis, a useful stain was found to be the PTAH, which stained the fibrin meshwork dis. tinctively even though the cells were autolyzed and unrecognizable.

A great disappointment was the inability to diagnose an acute myocardial infarction. The necrotic muscle was indistinguishable from the surrounding autolyzed myocardium. The process of necrosis in an infarct is essentially identical to autolysis. The blood flow in both cases ceases and the muscle dies. The distinction in an infarct is an acute inflammatory reaction at the periphery of the lesion. This reaction was found to be poorly preserved by mummification, and, as it does not begin until some six hours after the injury, will not appear in cases of immediate death. It must be conceded that the diagnosis of acute myocardial infarction, with all its implications for diet, life style, and the other factors that have been suggested in this disease, probably cannot be made in mummified tissue.

The diagnosis of a healed myocardial infarction, on the other hand, is more easily made as large areas of fibrosis are readily seen. An interesting point was the preservation of the myocardium adjacent to the healed infarct. The myocardial nuclei were easily seen, and this is certainly related to the hypertrophy which occurs in regenerative myocardium adjacent to an old infarct; the nuclei become large and hyperchromatic. Although shrinkage does occur with mummification, they are still better seen than normal cells. This phenomenon has certain implications for the preservation of tumor cells, as discussed below.

Chronic heart failure due to such fibrotic processes leads to passive congestion of various organs. Iron staining was useful in demonstrating the deposition of hemosiderin, the breakdown product of hemoglobin in chronic congestive states.

Another occlusive intravascular phenomenon is embolization, the ". . p partial or com- 
plete obstruction of some part of the vascular system by any mass carried there in the circulation." (Marchesi, '77: p. 176). The example studied was a case of bone marrow embolization to the lung. This condition is secondary to bone fracture. The emboli were easily recognized, and such a finding in a mummy should serve as a marker for a traumatic death, particularly useful as acute hemorrhage proved to be a problematic diagnosis.

In this study, malignant tumors were found to be better preserved by mummification than normal tissues. The pattern of replacement of normal structures, which the pathologist depends upon, is well preserved. The cytologic changes in malignancy are favorable to preservation as well. The enlarged and dark staining (hyperchromatic) nuclei of malignant cells retain these characteristics with mum. mification, remaining visibly larger and darker than adjacent normal nuclei. This contrast was well seen with lung tumors and tumors metastatic to the marrow and liver.

Almost all the tumors examined, other than those of the intestinal tract, were adequately preserved. Tumor products such as mucin and argentaffin granules could still be identified by appropriate special stains. A number of metastatic tumors could also be identified as to tissue of origin. The diagnosis of such tumors is of importance in that the autolysis by digestive juices of the gastrointestinal tract makes it unlikely that we will ever directly diagnose tumors of this organ system in mummies. The identification of metastatic adenocarcinoma in lung, liver, or bone will probably supply our only inferences as to the occurrence of cancer in the gastrointestinal tract. Confirmation of this hypothesis was seen in a colonic carcinoma. The bowel primary was autolyzed and undiagnosable, while the same lesion metastatic to the liver was actually better preserved than the surrounding liver.

It was found that some special stains, such as the Muci-carmine, did lose some of their specificity when applied to mummified tissue. These stains should be approached with some caution and used only as confirmatory rather than diagnostic evidence.

One of the great questions in paleopathology is the relative scarcity of tumors in ancient remains. There are only a handful of reports of tumors in the literature (Allison et al., '74; Hart, '73; Armelagos, '69; Brothwell, '67; Gray, '67; Wells, '64, Rowling, '61; Miller,
'29; Williams, '29; Ruffer and Willmore, '14); these are almost entirely lesions in skeletal material. I know of only two tissue diagnoses of tumors in mummies, both of benign skin tumors (Zimmerman, '78; Sandison, '67). A tentative diagnosis, unsubstantiated by photomicrographs, of malignant melanoma, has been made in Peruvian material (Urteaga and Pack, '66).

This scarcity of tumors has been attributed to the early death of individuals in ancient populations, before the "cancer age," or to inadequate examination of the material, either errors of omission or inability to distinguish tumors from postmortem artefact (Brothwell, '67). In modern populations bone tumors are most common in the second and third decades of life, as discussed above, and the absence of reports of such tumors in ancient skeletal material would appear to indicate either a true scarcity or very inadequate examination.

On the other hand, it must be remembered that bone tumors, either primary or metastatic, are rare, being far exceeded in number by tumors of the viscera, particularly the lung, breast, and gastrointestinal tract and lymphomas. These tumors account for a considerable proportion of deaths in modern populations, and even though the number of mummies examined is still relatively small, one would expect an incidence of something over zero. The complete absence of such lesions (which are more common in, but exclusively confirmed to, the elderly) would indicate either that they occurred only rarely or not at all in antiquity, or that the degree of preservation in mummified tissue would not be adequate for diagnosis by the paleopathologist.

The results of this study would indicate that the failure to diagnose cancer in mummies is not because of any technical difficulty, and suggests that the incidence of tumors in ancient material is truly (and astoundingly) lower than in modern populations.

There are very few references in the literature to the antiquity of cancer. The crab-like nature of malignant tumors (from which the name "cancer" derives) was only noted by the Greeks c. 500 A. D. (Krook, '69), although there are some older references to various tumors (Krook, '69; Butterfield, '66; Urteaga and Pack, '66). Perhaps more relevant to this discussion is the documentation of the first reports of certain cancers in the relatively recent past. These include multiple myeloma in 1840-50 (Clamp, '67), carcinoma of the nasal 
passages in snuff users in 1761 (Redmond, 70 ), and a variety of occupational tumors in the Eighteenth, Nineteenth and Twentieth Centuries (Shimkin, '75). Most of these are distinctive tumors, clinically and pathologically, and their late description suggests infrequency of occurrence until the relatively recent past. An increasing incidence of cancer throughout the world was noted by 1915 (Hoffman, '15).

Whatever the vagaries of the older medical literature are, the fact remains that there is not one single instance of a tissue diagnosis in mummies of cancer of the lung, cancer of the breast, cancer of the bowel, or any of the other myriad tumors which afflict our modern populations. This experimental study suggests that such tumors should be, if anything, better preserved than normal tissues and implies that carcinogenic factors present in the modern world were absent in antiquity. While the role of tobacco in carcinogenesis is well known (Steinfeld, '71), a discussion of the role of other factors in this secular trend such as diet, heredity, and ecologic considerations (industrial pollution, radiation, viruses, etc.), would be highly speculative and beyond the scope of this report.

\section{ACKNOWLEDGMENTS}

I thank Professors B. S. Blumberg, F. E. Johnston, and A. E. Mann for advice, and Mrs. D. Sheehan and her staff for technical assistance.

\section{LITERATURE CITED}

Aegerter, E., and J. A. Kirkpatrick, Jr. 1975 Orthopedic Diseases: Physiology, Pathology, Radiology. Fourth ed. Saunders, Philadelphia.

Allison, M. J., E. Gerszten and H. P. Dalton 1974 Paleopathology in preColumbian Americans. Lab. Invest., 30: 407-408.

Allison, M. J., D. Mendoza and A. Pezzia 1973 Documentation of a case of tuberculosis in preColumbian America. Am. Rev. Resp. Dis., 107: 985-991.

Angel, J. L. 1966 Porotic hyperostosis, anemias, malarias, and marshes in the prehistoric Eastern Mediterranean. Science, 153: 760-763.

Armelagos, G. J. 1969 Disease in ancient Nubia. Science, 163: 255-259.

Beatty, W. K. 1974 Medical numismatic notes, XV: Some medical aspects of Greek and Roman coins. Bull. N. Y. Acad. Med., 50: 85-95.

Bloch, H, 1973a Yellow fever in the city of New York. N. Y. State J. Med., 73: 2502-2503.

- 1973b Yellow fever epidemic in Philadelphia. N. Y. State J. Med., 73: 2606-2609.

Breasted, J. H. 1934 The Edwin Smith Surgical Papyrus. University of Chicago Press, Chicago.

Brothwell, D. 1967 The evidence for neoplasms. In: Diseases in Antiquity: A Survey of the Diseases, Injuries, and Surgery of Early Populations. D. Brothwell and A. T. Sandison, eds. C. C Thomas, Springfield, pp. 320-345.

Brothwell, D., ed. 1968 The Skeletal Biology of Earlier Human Populations. Pergamon, London.

Brothwell, D., and A. T. Sandison, eds. 1967 Diseases in Antiquity: A Survey of the Diseases, Injuries, and Surgery of Early Populations. C. C Thomas, Springfield

Brothwell, D., A. T. Sandison and P. H. K. Gray 1969 Human biological observations on a Guanche mummy with anthracosis. Am. J. Phys. Anthrop., 30: 333-347.

Butterfield, W. C. 1966 Tumor treatment, 3000 B. C Surg., $60: 476-479$.

Carter, H. R. 1931 Yellow Fever: An Epidemiological and Historical Survey of Its Place of Origin. Williams and Wilkins, Baltimore.

Clamp, J. R. 1967 Some aspects of the first recorded case of multiple myeloma. Lancet, $2:$ 1354-1356.

Coatney, G. R., W. E. Collins, W. McWilson and P. G. Contacos 1971 The Primate Malarias. Nat. Inst. Health, Bethesda, Maryland.

Cockburn, T. A. 1967 Infectious Diseases: Their Evolution and Eradication. C. C Thomas, Springfield.

- 1971 Infectious diseases in ancient populations. Curr. Anthrop., 12: 45-62.

Cockburn, T. A., R. Barraco, T. A. Reyman and W. H. Peck 1975 Autopsy of an Egyptian mummy. Science, 187: $1155 \cdot 1160$.

Cook, S.F. 1973 The significance of disease in the extermination of the New England Indians. Hum. Biol., 45: 485-508

Dawson, W. R. 1967 The Egyptian medical papyri. In: Diseases in Antiquity: A Survey of the Diseases, Injuries, and Surgery of Early Populations. D. Brothwell and A. T. Sandison, eds. C. C Thomas, Springfield, pp. 98-111.

Evans, W. E. D. 1963 Adipocere formation in a relatively dry environment. Med. Sci. Law., 3: 145-153.

Flanagan, D., ed. 1973 Life and death and medicine. Scient. Amer., 229 (3): 22-175.

Goldman, L. 1974 Pediatrics in art: An African brass miniature. Am. J. Dis. Child, 127: 690.

Goldstein, M. S. 1970 The paleopathology of human skeletal remains. In: Science in Archaeology. D. Brothwell and E. Higgs, eds. Praeger, New York, pp. 480-489.

Gray, P. H. K. 1967 Radiography of ancient Egyptian mummies. Med. Rad. Photog., 43: 34-44.

Hart, G. D. 1970 A hematological artefact from 4th century Britain. Bull. Hist. Med., 44: 76-79.

- 1973 The diagnosis of disease from ancient coins. Archaeol., 26: 123-127.

Hoffman, F. L. 1915 The Mortality from Cancer throughout the World. Prudential Press, Newark, N. J.

Janssens, P. A. 1970 Paleopathology: Diseases and Injuries of Prehistoric Man. John Baker, London.

Katz, R.S. 1974 Influenza 1918-1919: A study in mortality. Bull. Hist. Med., 48: 416-422.

Krook, J. 1969 Man's early challenge to neoplasms. Minn. Med., 52: 1159-1164.

Lichtenstein, L. 1970 Diseases of Bones and Joints. Mosby, St. Louis.

Lipson, L. G. 1972 Plague in San Francisco in 1900. Ann. Int. Med., 77; 303-310.

Livingstone, F. B. 1969 Gene frequency clines of the B hemoglobin locus in various human populations and their simulation by models involving differential selection. Hum. Biol., 41: 223-236.

Luna, L. 1968 Manual of Histologic Staining Methods of the Armed Forces Institute of Pathology. McGraw-Hill, New York.

Mant, A. K. 1957 Adipocere - A review. J. Forensic Med., 4: 18-35. 
Marchesi, V. T. 1977 Disturbances of body water and cir. culation of blood. In: Pathology. W. A. D. Anderson and J. M. Kissane, eds. Mosby, St. Louis, pp. 148-192.

Miller, J. L. 1929 Some diseases of ancient man. Ann Med. Hist., 1: 394-402.

Redmond, E. D. 1970 Tobacco and Cancer: The first clinical report, 1761. N. Eng. J. Med., 218; 18-23.

Reyman, 'T. A., M. R. Zimmerman and P. K. Lewin 1977 Autopsy of an Egyptian mummy (Nakht-ROM 1): Histopathologic investigation. Canad. Med. Assoc. J., 117: 470-472.

Riddle, J. M., K-L. Ho, J. L. Chason and R. C. Schwyn 1975 Peripheral blood elements found in an Egyptian mummy: A three-dimensional view. Science, 192: 374-375.

Reisman, D. 1935 The Story of Medicine in the Middle Ages. Hoeber, New York.

Rowling, J. T, 1961 Pathological changes in mummies. Proc. Roy Soc. Med., Sect. Hist. Med, 54: 409.425.

Ruffer, M. A. 1921 Studies in the Paleopathology of Egypt. University of Chicago Press, Chicago.

Ruffer, M. A., and J. G. Willmore 1914 Studies in paleopathology. Note on a tumor of the pelvis dating from Roman times (250 A.D.) and found in Egypt. J. Path. Bact., 18: $480-484$.

St. Hoyme, L. E. 1969 On the origins of New World paleopathology. Am. J. Phys. Anthrop., 31: 295-302.

Sandison, A. T. 1967 Diseases of the skin. In: Diseases in Antiquity: A Survey of the Diseases, Injuries, and Surgery of Early Populations. D. Brothwell and A. T. Sandison, eds. C. C Thomas, Springifled, pp. 449-456.

1970 The study of mummified and dried human tissues. In: Science in Archaeology. D. Brothwell and E. Higgs, eds. Praeger, New York, pp. 490-502.

Shaw, A. F. B. 1938 A histological study of the mummy of Har-mose, the singer of the 18th dynasty (circa 1490 B.C.). J. Path. Bact., 47: 115-123.

Shimkin, M. D. 1975 Some historical landmarks in cancer epidemiology. In: Cancer Epidemiology and Pre vention: Current Concepts. D. Schottenfeld, ed. C. C Thomas, Springfield, pp. 60-75.

Sloan, A. W. 1974 Plague in London under the early Stuarts. S. Afr. Med. J., 48: 882-888.
Stearn, E. W, and E. Allen 1945 The Effect of Smallpox on the Destiny of the Amerindians. Humphries, Boston.

Steinfeld, J. L. 1971 The Health Consequences of Smoking. A Report of the Surgeon General. Department of Health, Education and Welfare Publication No. (HAM) 71-7513, 239-244.

Stevenson, W. E., III 1975 The Pathological Grotesque Representation in Greek and Roman Art. Ph.D. Thesis, University of Pennsylvania, Department of Classical Archeology, Philadelphia.

Urteaga, O., and G. T. Pack 1966 On the antiquity of melanoma. Cancer, 19: 607-612.

von Hagen, V. W. 1964 The Desert Kingdoms of Peru Weidenfeld and Nicolson, London.

Wells, C. 1964 Two medieval cases of malignant disease. Brit. Med. J., 1: 1611-1612.

Wiesenfeld, S. L. 1967 Sickle-cell trait in human biologi$\mathrm{cal}$ and social evolution. Science, 157: 1134-1140.

Williams, H. U. 1929 Human paleopathology: With some original observations on symetrical osteoporosis of the skull. Arch. Path., 7: 839-902.

Wright-St Clair, R. E. 1974 The impact of infection on a Polynesian community. Canad. Med. Ass. J., 110 : 953-956.

Zimmerman, M. R. 1972 Histological examination of experimentally mummified tissues. Am. J. Phys. Anthrop., 37: $271-280$.

1973a The paleopathology of mummies: An annotated bibliography. Paleopath. Newsl.\#3: 11.15.

$1973 \mathrm{~b}$ Blood cells preserved in a mummy 2,000 years old. Science, 180: 303-304.

1977 The mummies of the tomb of Nebwenenef: Paleopathology and archeology. J. Am. Res. Cent. Egypt, 14: 33-36.

Zimmerman, M. R., and G. S. Smith 1975 A probable case of accidental inhumation of 1600 years ago. Bull. N. Y. Acad. Med., 51: 828-837.

Zimmerman, M. R., G. W. Yeatman, H. Sprinz and W. P. Titterington 1971 Examination of an Aleution mummy. Bull. N.Y. Acad. Med., 47: 80-103.

Zinsser, H. 1963 Rats, Lice and History. Little, Brown and Co., Boston. 
All photomicrographs were taken with a green filter. Staining was by hematoxylin and eosin unless otherwise specified. Magnification values are as printed.

\section{PLATE 1}

EXPIANATHON OF FIGURES

1a Fungal abcess, lung, fresh tissue. A mass of yeast forms and pseudohyphae, typical of Candida albicans, is present in an area of necrotic lung. Grocott. $\times 135$.

b Fungal abscess, lung, mummified tissue. The figure is virtually identical to the fresh tissue. Grocott. $\times 135$. 

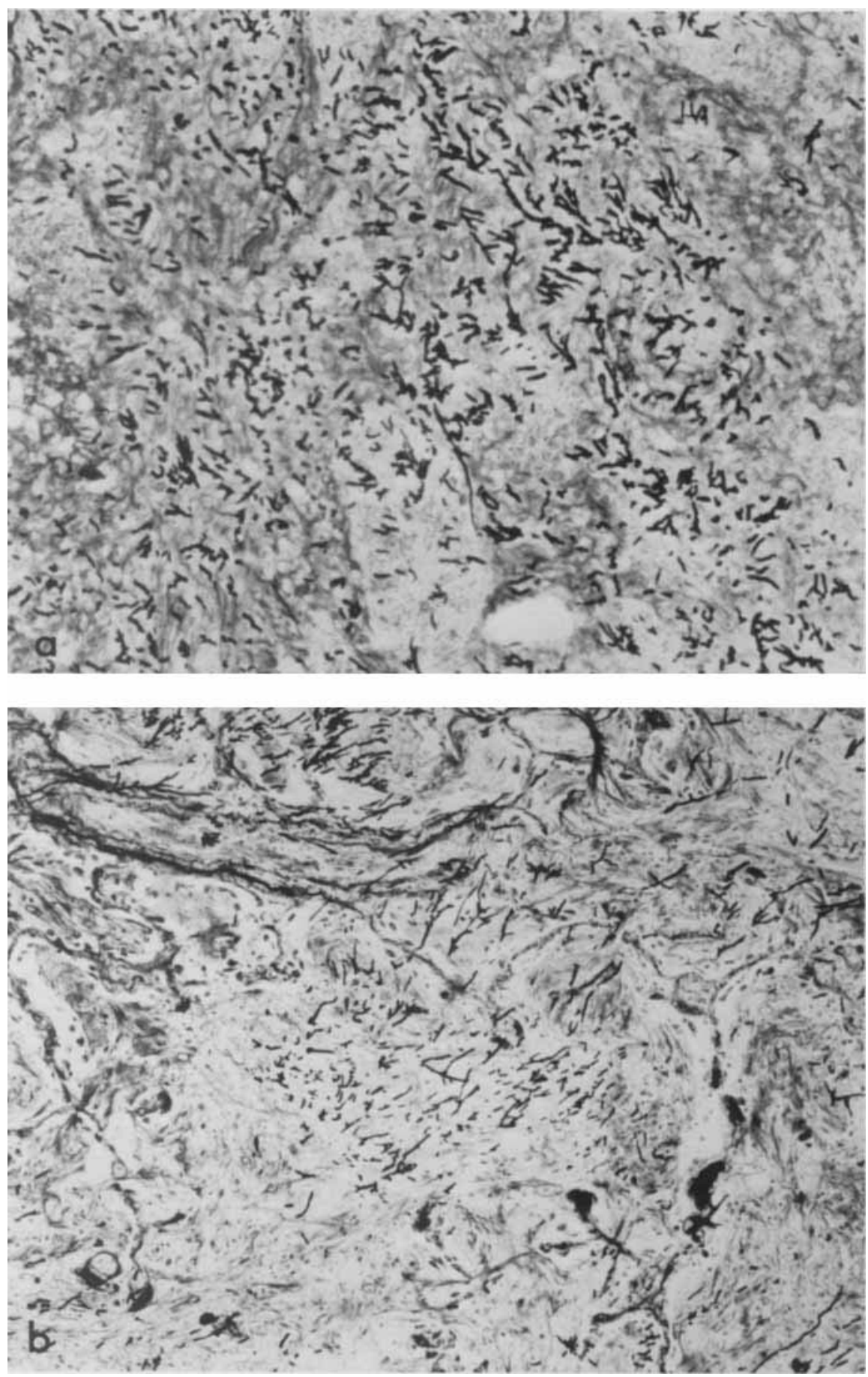
PLATE 2

EXPLANATION OF FIGURES

2a Cirrhosis, fresh tissue. The structure of the liver is disrupted by fibrous bands separating nodules of regenerating hepatocytes. There is severe fatty change as well. Trichrome. $\times 32.5$.

b Cirrhosis, mummified tissue. There is excellent preservation of both the fibrous bands and the intervening fatty liver. Trichrome. $\times 32.5$. 

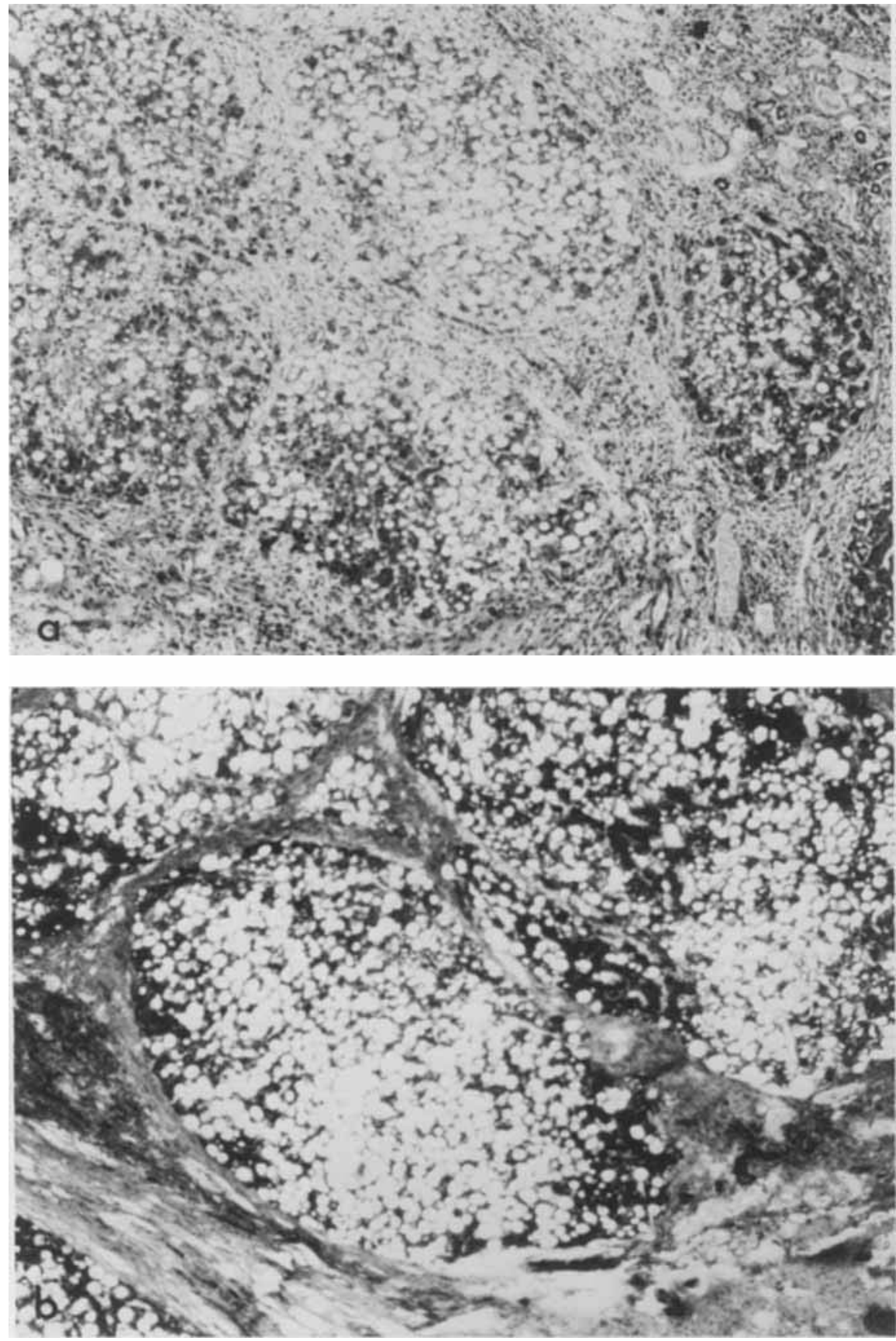


\section{PLATE 3}

\section{EXPLANATION OF FIGURES}

3a Bone marrow embolus, lung, fresh tissue. The vessel in the center is occluded by a mass of bone marrow material. $\times 135$.

b Bone marrow embolus, lung, mummified tissue. The marrow elements have partially autolyzed, making the adipose tissue element more prominent than in the fresh tissue. $\times 135$. 

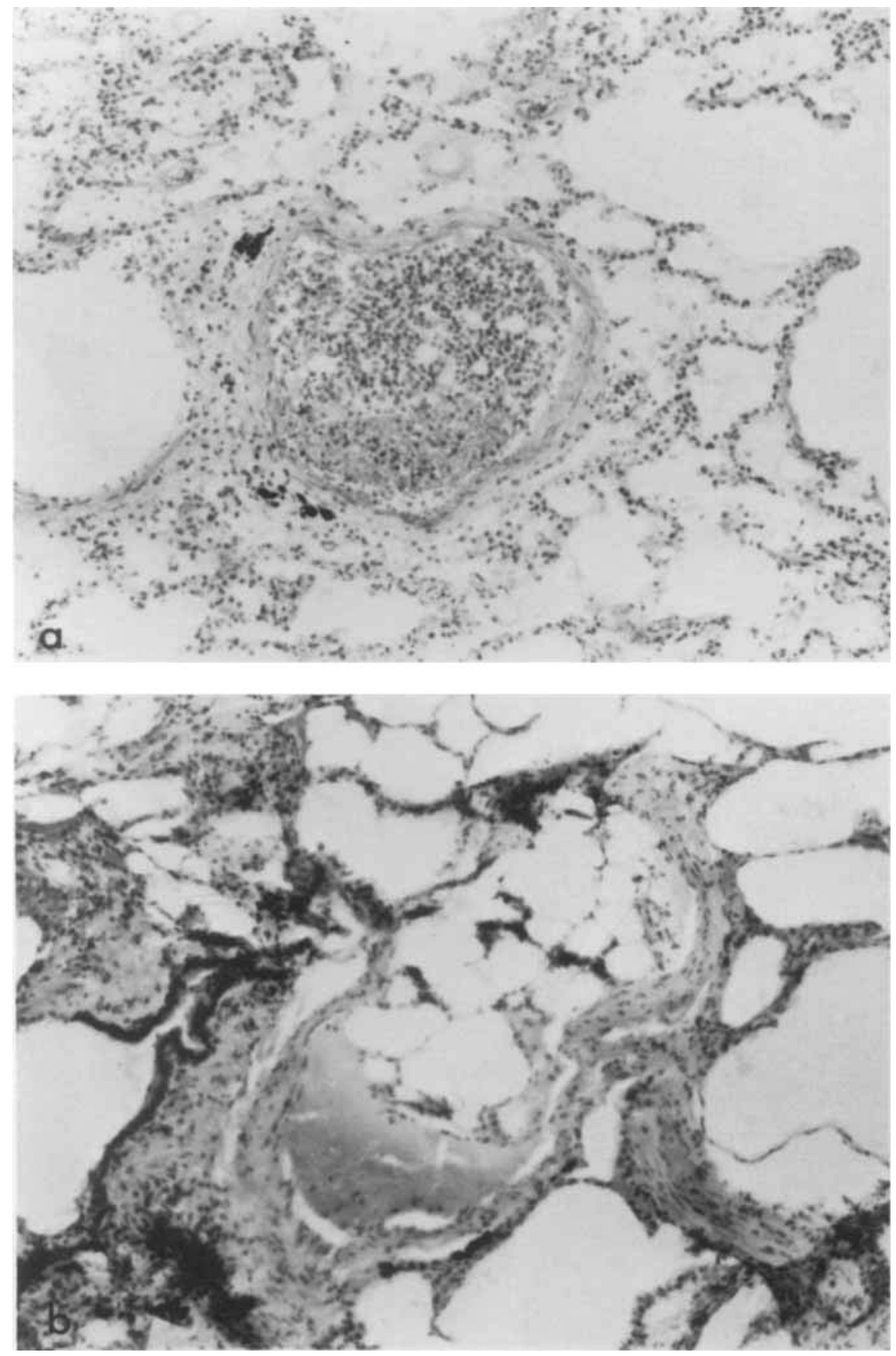


\section{PLATE 4}

EXPLANATION OF FIGURES

4a Carcinoma of breast, fresh tissue. The tumor consists of rows and shets of infiltrating dark cells. $\times 135$.

b Carcinoma of breast, mummified tissue. The infiltrating pattern is well seen, although individual cells are not preserved. $\times 135$. 

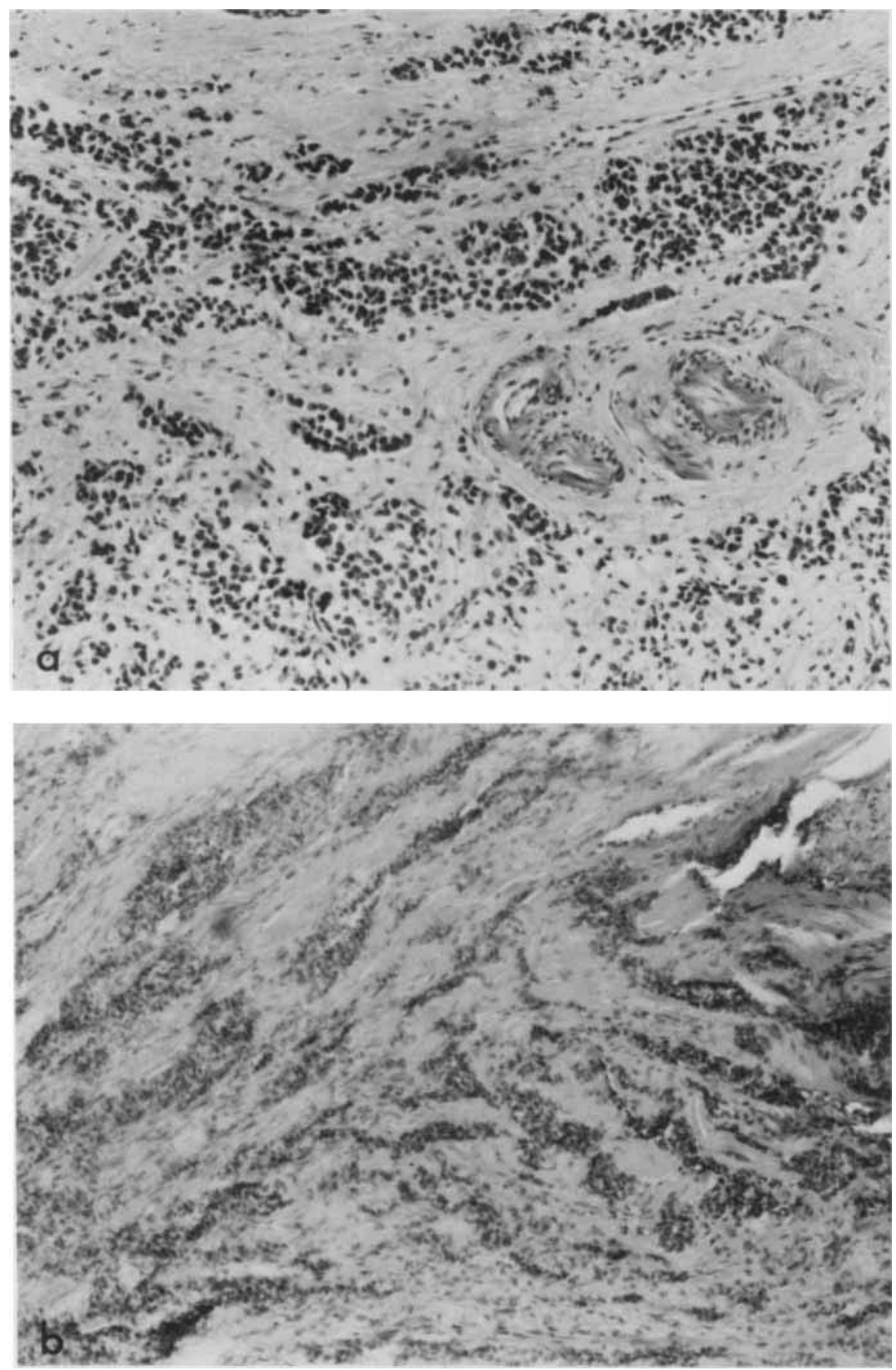


\section{PLATE 5}

\section{EXPLANATION OF FIGURES}

5a Metastatic adenocarcinoma, liver, fresh tissue. The tumor (on the right) shows the large dark nuclei typical of malignancy. $\times \mathbf{1 3 5}$.

b Metastatic adenocarcinoma, liver, mummified tissue. While the liver has completely autolyzed, the tumor remains recognizable as sheets of dark staining nuclear material. $\times 135$ 

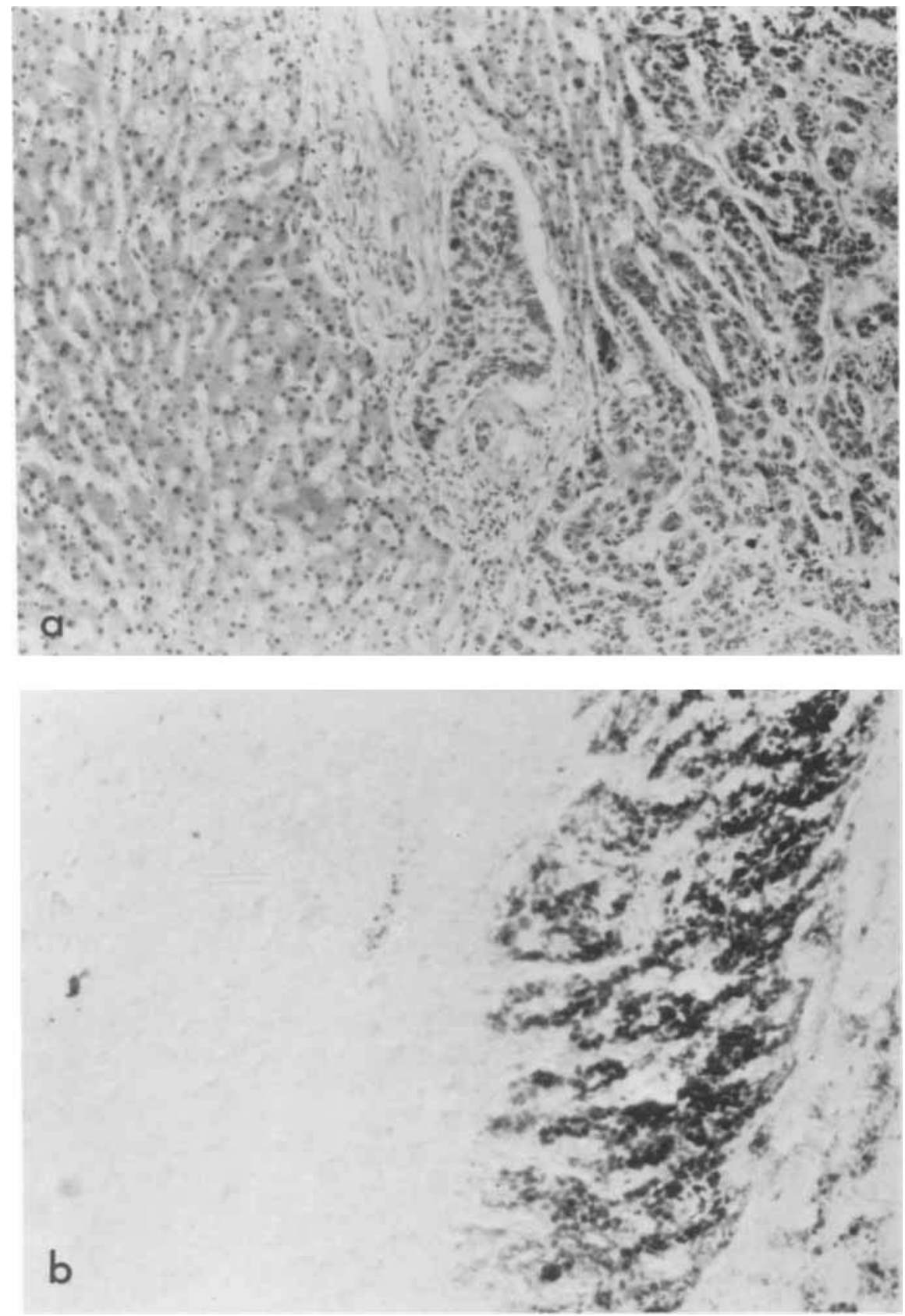